\title{
Nursing documentation in palliative care: An integrative review
}

\author{
Owen Doody ${ }^{1 *}$, Maria E. Bailey ${ }^{1}$, Sue Moran² and Kate Stewart ${ }^{1}$
}

*Correspondence: owen.doody@ul.ie

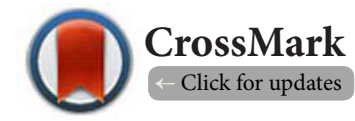

'Department of Nursing and Midwifery, University of Limerick, Ireland.

${ }^{2}$ Milford Care Centre, Castletroy, Limerick, Ireland.

\begin{abstract}
Purpose: Nursing documentation is essential in ensuring communication between team members, continuity of care and evidence based practice. The purpose of this paper is to review and synthesise research pertaining to nursing documentation in specialist palliative care.

Method: An Integrative review (IR) utilising Whittemore and Knafi's five stage process was employed. Electronic searches of: Scopus, Medline, Cinahl, Web of Science, Academic Search Complete databases (2010-2017) were conducted. 10,842 articles were retrieved which were reduced to five articles for review. Data extraction, quality assessment (Critical Appraisal Skills Programmes - CASP) and thematic analysis were conducted on the included articles.

$\underline{\text { Results: }}$ Two overarching themes emerged in this review, symptom management and engagement. Symptom management focused on documentation of symptoms while engagement highlighted emotional care, information giving, providing support, coordinating care, supporting families and education.

Conclusions: Clear, accurate, and complete documentation is crucial to the delivery of quality health care and pivotal to effective communication within the team. Although this is important in all aspects of care it is arguably even more so in end of life care. In order to audit the care provided, such care must be clearly identified and documented.
\end{abstract}

Keywords: Palliative care, documentation, care provision, continuous professional development

\section{Introduction}

The World Health Organizations [1] position on palliative care describes the total care of patients in order to achieve the best possible quality of life for patients and their families, encompassing care of body, mind, and spirit. Inherent to the delivery of safe, ethical and effective nursing practice is clear accurate and comprehensive documentation [2,3]. Documentation refers to any written information regarding a patient that describes their status or the care/services provided to the patient by a nurse [4]. In addition nursing documentation serves as a legal document, contributes credibility to nursing practices and enhances the professional image and presence of nurses [5]. The nursing process of; assessment, planning, implementation and evaluation has frequently been used as a framework for documentation across various care settings [6]. When caring for a patient, nurses' documentation provides a clear picture of; the status of the patient, the actions of the nurse and care outcomes [4]. Clear and coherent documentation can prevent negative outcomes caused by miscommunication [7]. Nursing documentation is a communication tool demonstrating not only evidence of what the nurse actually does for the patient, but also provides a tool to audit the written record of the patient's journey [8]. While having clear documentation is an essential requirement for nursing practice, there is also a need for the profession to make their contribution to healthcare visible [9-11].

While nurses recognise that documentation is important, their first priority and focus has been on patient care with documentation a lower priority [12]. Over the last few decades nursing has developed towards independent practice with explicit knowledge of nursing care. However, these developments require nurses' not only to perform interventions but also document their decision making processes and identify why 
Doody et al. Journal of Nursing 2018,

a nursing action has been prompted [13]. Nursing practice requires documentation to ensure continuity of care, planning, and accountability, as well as the promotion and uptake of evidence-based practice [14]. Nursing documentation provides an efficient way to communicate crucial patient information with members of the healthcare team [3]. Although this is important in all aspects of care it is arguably even more so in end of life care [15] as this may be the last opportunity to provide patients and their families with 'impeccable assessment and management of symptoms' [1] and thus positively influencing the grieving processes following a death. In nursing practice physical care needs are generally easy to identify and document. However, other aspects of care may be less easily identified and communicated to others for example; psychological care (empathy, communication, comfort, and support), social care (isolation/connections, feeling safe, effects of role changes on individuals and patient being involved in his/her own care) and spiritual care (being present, applying meaning to their journey and working with changing hopes).

This paper focuses on palliative care nursing documentation through an integrative review and aims to identify what nurses in this area of care document. Such a review is necessary in order to identify whether or not nursing documentation reflects the provision of palliative care as positioned by the World Health Organization [1].

\section{Methods}

The review utilised Whittemore and Knafi [16] framework and was conducted and reported in five stages (problem identification, literature search, data evaluation and extraction, data analysis, and presentation of results). Particular attention was paid to the development of the review question, search strategy, appraisal of study quality and method, identification of common aspects, and formation of themes for presentation.

\section{Stage 1: Problem identification}

A clear problem identification and review purpose provided focus, boundaries and facilitated all stages of the review. To assist with the review a clear identification of the problem variables of interest (concepts, target population, health care problem) and appropriate sampling frame (type of empirical studies, inclusion of theoretical literature) was developed. Using PEO framework (Population, Exposure and Outcome [17] Table 1).

Exploratory investigations highlighted a number of different terms encompassing palliative care including: end of life care, terminal care, hospice, life limiting condition, life threatening illness, cancer care, and specialist palliative care. Reviewing

Table 1. PEO Framework formulating the literature review question.

\begin{tabular}{ll}
\hline P - Population, & palliative care nurses' \\
E - Exposure & 'care' \\
$\mathrm{O}$ - Outcome & 'documentation' \\
\hline
\end{tabular}

a broad range of terms is central in providing a comprehensive understanding of the topic area [18]. Search parameters which guided the inclusion of papers are presented in Table 1. The time period (01 January 2010 to 10 January 2017) was identified as appropriate to ensure currency of relevant literature and reflect developments in palliative care and nursing practice. This seven year search period was chosen to reflect current evidence based knowledge regarding nursing documentation of palliative care and deemed as appropriate given the scope of integrative reviews to include a range of studies for different designs.

\section{Stage 2: Literature search}

The data-bases Scopus, Medline, Cinahl, Web of Science and Academic Search Complete were searched within the review parameters (Table 2). Boolean and Truncation were used to capture relevant variations of terms (Table 3). Finally an ancestry search of the reference lists of the identified studies was conducted.

Table 2. Search parameters.

\begin{tabular}{ll}
\hline Inclusion criteria & Exclusion criteria \\
\hline $\begin{array}{l}\text { Nursing documentation in } \\
\text { palliative care environments }\end{array}$ & $\begin{array}{l}\text { Studies that reported on } \\
\text { advanced care planning, } \\
\text { survivorship care planning or } \\
\text { cancer care planning. }\end{array}$ \\
\hline $\begin{array}{l}\text { Papers from peer reviewed } \\
\text { journals published from 01 }\end{array}$ & Non-peer reviewed studies \\
January 2010- 10 January 2017 & Non-English articles \\
\hline Articles written in English & $\begin{array}{l}\text { Review articles that did not use } \\
\text { a systematic process to identify } \\
\text { the literature }\end{array}$ \\
\hline $\begin{array}{l}\text { Original quantitative, qualitative integrative literature } \\
\text { and systematic reviews }\end{array}$ & \\
\hline
\end{tabular}

Table 3. Search strategy.

Search 1 - nurs ${ }^{\star}$ documentation OR nurs ${ }^{\star}$ record OR nurs ${ }^{\star}$ note $^{\star}$ OR care plan* OR nurs ${ }^{\star}$ kardex

Search 2 - palliative care OR end of life care OR terminal care OR hospice OR life limiting condition* OR life threatening illness OR cancer care OR specialist palliative care

Search 3 - search $1+\operatorname{search} 2$

The results of the computerised search process are presented in PRISMA format in Figure 1 where 5 articles, 4 quantitative studies and 1 qualitative study were identified for inclusion in this review. The articles country of origin included Norway $(n=1)$, Canada $(n=1)$, USA $(n=2)$ and Sweden $(n=1)$. The initial search identified 10842 results from which 2629 duplicates were removed. The remaining 8213 papers were screened broadly by title review and 8013 papers were omitted following this process. Of the remaining 200 papers an abstract review was conducted with 187 papers excluded as not meeting the criteria outlined in Table 2. A full text review of the remaining 


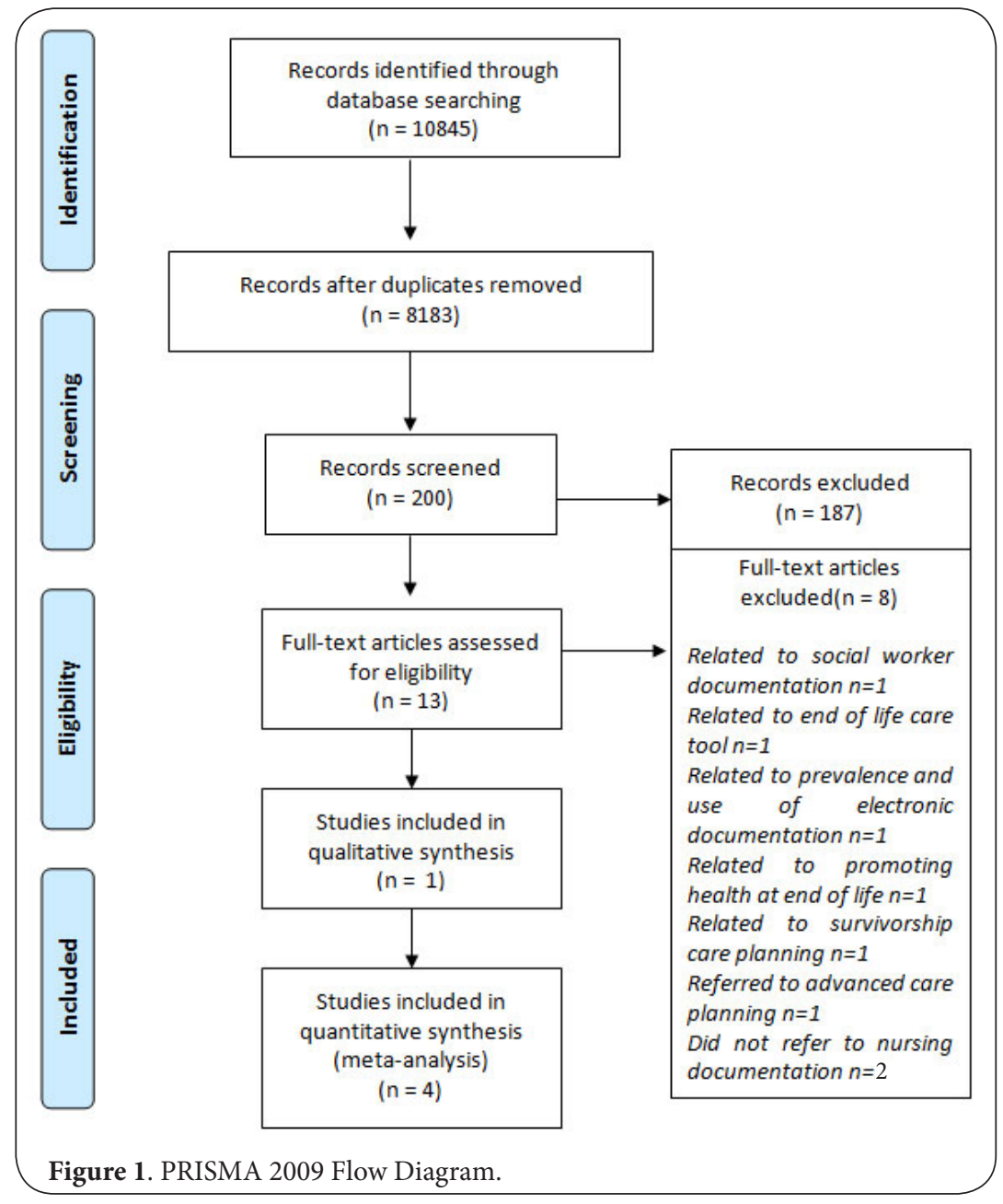

13 articles was completed by two independent assessors to identify if they met the inclusion/exclusion criteria (Table 2). The independent reviewers met to discuss the articles and based on their independent review an agreement was reached that; 8 further papers not meeting the criteria were excluded. The reference lists of the identified studies did not yield any additional papers. The search and application of the inclusion/ exclusion criteria resulted in 5 articles identified for inclusion in this review (Figure 1).

\section{Stage 3: Data evaluation and extraction}

Studies were appraised using the Critical Appraisal Skills Programmes Checklists [20] and graded low, medium or high. However as the review sought to extract key principles from the studies no disqualifications were made on the grounds of quality rather the quality assessment process assisted in building a picture of the underlying assumptions and methods that currently characterise the field. Initial data extraction captured the study characteristics including, setting, design of study, sample strategy, data collection and key issues identified in the research (Table 4) and subsequent data extraction collating findings into themes.

\section{Stage 4: Data analysis}

Within data analysis, data were ordered, coded, categorised and summarised into a unified and integrated conclusion. Themes were identified from each study and synthesised to form final themes. This was an iterative process of engagement and re-engagement with the studies where the findings of all included studies were carefully read line by line. Extracted information was compared and patterns recorded as they became apparent. This comparative analysis process was further scrutinised and discussed by the reviewers and it was possible to discern groupings of similar information leading to the identification of two key themes. Given the heterogeneity of the included literature meta-analysis was not undertaken and given that only one qualitative study was included metasynthesis or discourse analysis was not possible. Therefore, a narrative synthesis of extracted data was undertaken (Table 4) with emerging thematic headings. This allowed for coding according to similarities and differences and verification for accuracy and relevancy by all reviewers [21] and data in each 
Doody et al. Journal of Nursing 2018,

http://www.hoajonline.com/journals/pdf/2056-9157-5-3.pdf

doi: 10.7243/2056-9157-5-3

Table 4. Data extraction table.

\begin{tabular}{|c|c|c|c|c|c|c|}
\hline $\begin{array}{l}\text { Author, Publication } \\
\text { year, Title, and } \\
\text { Country }\end{array}$ & Study aim & Methodology/design & $\begin{array}{l}\text { Sample strategy } \\
\text { and sample size }\end{array}$ & $\begin{array}{l}\text { Data collection } \\
\text { method }\end{array}$ & Analytical approach & $\begin{array}{l}\text { Summary of main findings and quality } \\
\text { assurance }\end{array}$ \\
\hline $\begin{array}{l}\text { Esper, P., } \\
\text { Walker, S. } \\
\text { (2015) } \\
\text { 'Improving } \\
\text { documentation of } \\
\text { quality measures in } \\
\text { the electronic } \\
\text { health record' } \\
\text { United States }\end{array}$ & $\begin{array}{l}\text { Nurse Practioners } \\
\text { (NP) documentation } \\
\text { quality oncology } \\
\text { practice initiative } \\
\text { (QOPI) measures in } \\
\text { the electronic health } \\
\text { record(EHR) is } \\
\text { evaluated in this } \\
\text { study. }\end{array}$ & $\begin{array}{l}\text { Retrospective review } \\
\text { of medical charts } \\
\text { completed in August } \\
\text { of } 2012 \text {. }\end{array}$ & $\begin{array}{l}100 \text { medical charts } \\
\text { of Cancer Center } \\
\text { patients. }\end{array}$ & $\begin{array}{l}100 \text { medical charts } \\
\text { reviewed for evidence } \\
\text { of select supportive } \\
\text { care QOPI measures. } \\
\text { Areas of deficiency in } \\
\text { documentation were } \\
\text { identified and used to } \\
\text { develop an educational } \\
\text { intervention } \\
\text { (EI) for the NP staff. }\end{array}$ & $\begin{array}{l}\text { Data analyzed using } \\
\text { SPSS software. } \\
\text { The areas to be used in } \\
\text { the EI were based on a } \\
\text { selected } 80 \% \\
\text { compliance level. }\end{array}$ & $\begin{array}{l}\text { Main Findings: } \\
\text { Pre EI chart audit of } 100 \text { records was } \\
\text { reviewed for measures that fell below } \\
80 \% \text { compliance level and identified: } \\
\text { Documentation and appropriateness of } \\
\text { management plan for addressing } \\
\text { moderate to severe pain. } \\
\text { Documentation of basement, } \\
\text { management and review of intervention } \\
\text { for pain, bowel management, addressing } \\
\text { emotional well-being, oral chemotherapy } \\
\text { management. } \\
\text { Quality assurance: } \\
\text { This project utilised quality measures that are } \\
\text { included in QOPI chart reviews to obtain a } \\
\text { rapid and objective measurementof practice } \\
\text { quality. Limitations were noted by the } \\
\text { authors. }\end{array}$ \\
\hline $\begin{array}{l}\text { Freeman, S., } \\
\text { Hirdes, J.P., } \\
\text { Stolee, P., } \\
\text { Garcia, J., } \\
\text { Frise Smith, T., Steel, } \\
\text { K, } \\
\text { Morris, J.N. } \\
\text { (2014) } \\
\text { 'Care planning needs } \\
\text { of palliative home } \\
\text { care } \\
\text { clients:Development } \\
\text { of the interRAI } \\
\text { palliative care } \\
\text { assessment clinical } \\
\text { assessment protocols } \\
\text { (CAPs)' } \\
\text { Canada }\end{array}$ & $\begin{array}{l}\text { To describe the } \\
\text { interRAI PC CAP } \\
\text { development process } \\
\text { and provide an } \\
\text { overview of } \\
\text { distributional } \\
\text { properties of the } \\
\text { eight interRAI PC } \\
\text { CAPs among } \\
\text { community dwelling } \\
\text { adults receiving } \\
\text { palliative home care } \\
\text { services. }\end{array}$ & $\begin{array}{l}\text { Secondary data } \\
\text { analysis used } \\
\text { interRAI PC } \\
\text { assessments ( } \mathrm{n}= \\
6,769 \text { ) collected as } \\
\text { part of regular } \\
\text { clinical practice at } \\
\text { baseline ( } \mathrm{n}=6,769 \text { ) } \\
\text { and follow-up ( } \mathrm{n}= \\
1,000 \text { ). Clients across } \\
\text { six regional } \\
\text { jurisdictions in } \\
\text { Ontario, } \\
\text { Canadaassessed to } \\
\text { receive palliative } \\
\text { homecare services } \\
\text { between } 2006 \text { and } \\
2011 \text { were included } \\
\text { (mean age } 70.0 \text { years; } \\
\pm 13.4 \text { years). } \\
\text { Descriptive analyses } \\
\text { focused on the eight } \\
\text { interRAI PC CAPs: } \\
\text { Fatigue, Sleep } \\
\text { Disturbance, } \\
\text { Nutrition, Pressure } \\
\text { Ulcers, Pain, } \\
\text { Dyspnea, Mood } \\
\text { Disturbance and } \\
\text { Delinum. }\end{array}$ & $\begin{array}{l}\begin{array}{l}\text { Data were collected } \\
\text { from }\end{array} \\
\text { sixCommunity Care } \\
\text { Access Centre's } \\
\text { (CCAC). Pilot sites } \\
\text { were located across } \\
\text { geographical } \\
\text { regions and ranged } \\
\text { fromprimanily } \\
\text { metropolitan urban } \\
\text { to more rural and } \\
\text { geographically } \\
\text { dispersed districts. } \\
\text { Each CCAC is } \\
\text { tasked to coordinate } \\
\text { specialised } \\
\text { supports, including } \\
\text { palliative care, for } \\
\text { persons under its } \\
\text { jurisdiction. }\end{array}$ & $\begin{array}{l}\text { De-identified cross- } \\
\text { sectional pilot data } \\
\text { from } 6,769 \text { interRAI } \\
\text { PC assessments } \\
\text { gathered between } 2006 \\
\text { and } 2011 \text { from } \\
\text { palliative home care } \\
\text { clients in Ontario, } \\
\text { Canada were included } \\
\text { for analysis. }\end{array}$ & $\begin{array}{l}\text { Univariate } \\
\text { distributional } \\
\text { properties were } \\
\text { examined for all eight } \\
\text { interRAI PC CAPs and } \\
\text { cross tabulations were } \\
\text { used to examine the } \\
\text { hierarchical triggering } \\
\text { structure of the CAPs. } \\
\text { Associated covariates } \\
\text { including age, gender, } \\
\text { estimated prognosis, } \\
\text { geographic location, } \\
\text { and disease diagnosis, } \\
\text { were examined using } \\
\text { chl-square to determine } \\
\text { significant } \\
\text { relationships. Chi } \\
\text { square analysis was } \\
\text { employed to examine } \\
\text { covariates among } \\
\text { CAPs. All analyses } \\
\text { were performed using } \\
\text { SAS Version } 9.2 \text { with } \\
\text { an alpha level of p } \\
<0.05 \text { for all statistical } \\
\text { tests. }\end{array}$ & $\begin{array}{l}\text { Main findings: } \\
\text { Nearly } 9 \text { in } 10 \text { persons triggered at least } \\
\text { one CAP ( } 87.9 \%, n=5,950 \text { ) and } \\
\text { approximately two thirds triggered more } \\
\text { than two CAPs. } \\
\text { The interRAI PC Clinical Assessment } \\
\text { Protocols (CAPs) focus on specific } \\
\text { clinical, functional, and life quality } \\
\text { issues. Using algorithms embedded } \\
\text { within the inter RAI PC, the CAPs alert } \\
\text { the assessor to specific problems and } \\
\text { indicate either risk of their appearance or } \\
\text { potential for improvement, if present. } \\
\text { Both can be addressed in the care plan. } \\
\text { Each CAP contains four combonents: } \\
\text { 1ssue statement, goals of care, trggers, } \\
\text { and guidelines. } \\
\text { Triggering rates ranged from } 74 \% \text { for the } \\
\text { Fatigue to less than } 15 \% \text { for the } \\
\text { Delinum and Pressure Ulcers. } \\
\text { The hierarchical CAP triggering } \\
\text { structure suggested Fatigue and Dyspnea } \\
\text { CAPs were persistent issues prevalent } \\
\text { among the majority of clients while } \\
\text { Delinum and Pressure Ulcers CAPs } \\
\text { rarely trigger in isolation and most often } \\
\text { trigger later in the illness trajectory. } \\
\text { Fatigue was the most commonly } \\
\text { triggered CAP, triggered by } 38.9 \% \text { of } \\
\text { persons who triggered only one CAP to } \\
\text { over } 90 \% \text { of persons who triggered three } \\
\text { to five CAPs and } 100 \% \text { of persons to } \\
\text { triggered six or more CAPs. Captured in } \\
\text { the percentage of persons who trigger } \\
\text { only one CAP, the Fatigue CAP, Pain } \\
\text { CAP, Nutrition CAP, and Dyspnea CAP } \\
\text { emerged as early-triggered CAPs. } \\
\text { In contrast, theDelinum and Pressure } \\
\text { Ulcer CAPs emerged as latetriggered } \\
\text { CAPs. Consequently, persons who } \\
\text { triggered only one CAP, were most } \\
\text { likely to trigger the Fatigue, Pain, } \\
\text { Nutrition, or Dyspnea CAPs and were } \\
\text { least likely to trigger the Delinium CAP } \\
\text { and Pressure Ulcer CAP. } \\
\text { Quality assurance: } \\
\text { Three phase development process - } \\
\text { review, consultation with } \\
\text { experts,creation of triggering algorithms. } \\
\text { Spearman rank correlations suggest } \\
\text { majority of CAPs are reasonably } \\
\text { independent from each other (modest } \\
\text { correlations between Fatigue and }\end{array}$ \\
\hline
\end{tabular}


Doody et al. Journal of Nursing 2018,

\section{Continuation of Table 4}

\begin{tabular}{|c|c|c|c|c|c|c|}
\hline & & & & & & $\begin{array}{l}\text { Delinum CAPS and Fatigue andMood } \\
\text { Disturbance CAPS). } \\
\text { Difficult to tell how bias and } \\
\text { confounding factors were controlled for. } \\
\text { The sample is sufficiently large and } \\
\text { differences may be statistically } \\
\text { significant at the level, but of modest } \\
\text { clinical importance. }\end{array}$ \\
\hline $\begin{array}{l}\text { Ohlen, C.A., } \\
\text { Forsberg, C., } \\
\text { Broberger, E. } \\
\text { (2013) } \\
\text { 'Documentation of } \\
\text { Nursing Care in } \\
\text { advanced Home Care' } \\
\text { Sweden }\end{array}$ & $\begin{array}{l}\text { The aim of this } \\
\text { study was to } \\
\text { describe } \\
\text { documentation of } \\
\text { nursing care within } \\
\text { AHC. }\end{array}$ & $\begin{array}{l}\text { Descriptive } \\
\text { qualitative design } \\
\text { using document } \\
\text { analysis with } \\
\text { inspiration from } \\
\text { content analysis } \\
\text { according to Elo and } \\
\text { Kyngäs }\end{array}$ & $\begin{array}{l}\text { Sixty nursing } \\
\text { records from two } \\
\text { AHC-units in } \\
\text { Stockholm } \\
\text { Swedenwere } \\
\text { collected. } \\
\text { Thirty patient } \\
\text { records estimated to } \\
\text { be two thirds of the } \\
\text { records from } \\
\text { patients admitted to } \\
\text { the AHC unit at the } \\
\text { time of data } \\
\text { collection were } \\
\text { randomly collected } \\
\text { from each unit. } \\
\text { The patients had } \\
\text { been enrolled in } \\
\text { AHC between } \\
25 \text { to } 208 \text { days, } \\
\text { median } 124 \text { days, } \\
\text { andmean } 122 \text { days. }\end{array}$ & $\begin{array}{l}30 \text { computerised } \\
\text { records randomly select } \\
\text { from currently admitted } \\
\text { patients. } \\
\text { The records were } \\
\text { anonymous for the } \\
\text { researchers and } \\
\text { dataprepared in a way } \\
\text { so that it could not be } \\
\text { traced to a specific } \\
\text { patient, nurse, or the } \\
\text { patient's family. }\end{array}$ & $\begin{array}{l}\text { Document analysis } \\
\text { with inspiration from } \\
\text { content analysis } \\
\text { according to Elo and } \\
\text { Kyngäs was used. The } \\
\text { analysis process } \\
\text { consists of three } \\
\text { phases: preparing, } \\
\text { organising, and } \\
\text { reporting data. Only } \\
\text { the manifest content } \\
\text { was analysed using an } \\
\text { inductive approach. } \\
\text { The analysis was } \\
\text { executed manually. }\end{array}$ & $\begin{array}{l}\text { Main Findings: } \\
\text { Results revealed documentation } \\
\text { of advanced nursing care from a broad } \\
\text { spectrum, consisting of both planned and } \\
\text { acute care. Documentation was often } \\
\text { fragmented and information sometimes } \\
\text { hard to find. Nursing documentation } \\
\text { often described caring needs, but lacked } \\
\text { interventions andevaluations. } \\
\text { Planned care. } \\
\text { The most frequently documented nursing } \\
\text { care was performed according to a } \\
\text { predetermined care plan or by } \\
\text { subscription from a physician and } \\
\text { consisted mainly of medical technical } \\
\text { interventions. These consisted of } \\
\text { provision of information and education, } \\
\text { coordination and team work, and } \\
\text { administration. } \\
\text { Acute Care } \\
\text { Nurses performed acute care mainly due } \\
\text { to emergency calls mostly frompatients } \\
\text { but also from family members. The most } \\
\text { common documented reasons for } \\
\text { emergency calls were pain, and } \\
\text { unexpected bleeding or fever related to } \\
\text { infections. Standingprescriptions of } \\
\text { medication to take whenneeded were } \\
\text { actioned or contact with a physician. The } \\
\text { decision for admission to hospital was } \\
\text { documented. } \\
\text { Quality assurance: } \\
\text { All authors participated in analysing the } \\
\text { process and a critical revision of the } \\
\text { analysis. Process of analysis provided. } \\
\text { An advisory statement was obtained } \\
\text { from the regional ethical committee. }\end{array}$ \\
\hline $\begin{array}{l}\text { Almasalha, F., } \\
\text { Xu, D., } \\
\text { Keenan, G.M., } \\
\text { Khokhar, A., } \\
\text { Yao, Y., } \\
\text { Chen, Y.C., Johnson, } \\
\text { A., } \\
\text { Ansari, R., } \\
\text { Wilkie, D.J. } \\
\text { (2012) } \\
\text { 'Data Mining Nursing } \\
\text { Care Plans of End-of- } \\
\text { Life Patients: A Study } \\
\text { to Improve Healthcare } \\
\text { Decision Making' } \\
\text { USA }\end{array}$ & $\begin{array}{l}\text { To reveal hidden } \\
\text { pattems and } \\
\text { knowledge present } \\
\text { in nursing care } \\
\text { information } \\
\text { documented with } \\
\text { standardized nursing } \\
\text { terminologies on } \\
\text { end-of-life } \\
\text { (EOL) hospitalized } \\
\text { patients. }\end{array}$ & $\begin{array}{l}\text { Quantitative analysis } \\
\text { of care plans and } \\
\text { nursing } \\
\text { documentation using } \\
\text { association mining, } \\
\text { clustering, and } \\
\text { classification } \\
\text { techniques to glean } \\
\text { hidden information. }\end{array}$ & $\begin{array}{l}\text { Convenience } \\
\text { sampling to select } \\
\text { units - Four agreed } \\
\text { to participate; two } \\
\text { large community } \\
\text { hospitals, one } \\
\text { university hospital, } \\
\text { and one small } \\
\text { community } \\
\text { hospital. Eight units } \\
\text { recruited from these } \\
\text { hospitals to } \\
\text { participate for } \\
\text { either a } 12 \text {-month } \\
\text { (fourunits) or } 24- \\
\text { month (four units) } \\
\text { study period. Data } \\
\text { derived from a } \\
\text { primary dataset } \\
\text { gathered on } 33,451 \\
\text { medical surgical } \\
\text { patients ( } 40,747 \\
\text { unique episodes). } \\
\text { With analyses } \\
\text { conducted on a } \\
\text { subset of } 1,425 \\
\text { EOL episodes } \\
\text { derived from the } \\
\text { primary dataset. }\end{array}$ & $\begin{array}{l}\text { The data were } \\
\text { extracted from the } \\
\text { Hands-On Automated } \\
\text { Nursing Data System } \\
\text { database of nursing } \\
\text { care plan episodes } \\
\text { coded with NANDA-I, } \\
\text { Nursing Outcomes } \\
\text { Classification, and } \\
\text { Nursing Intervention } \\
\text { Classification (NNN) } \\
\text { terminologies. }\end{array}$ & $\begin{array}{l}\text { Statistical analysis } \\
\text { using SPSS with t-tests } \\
\text { or chi-square tests. } \\
\text { Two-tailed alpha level } \\
\text { of } .05\end{array}$ & $\begin{array}{l}\text { Main findings: } \\
\text { Only } 41.3 \% \text { of care plans included pain, } \\
55 \% \text { of patients were discharged to a } \\
\text { hospice with worse pain than expected. } \\
\text { The most effective nursing intervention } \\
\text { classificationpainintervention was only } \\
\text { used in } 81 / 596 \text { cases. } \\
\text { Standardised teminology can more } \\
\text { effectively demonstrate nursing } \\
\text { knowledge within documentation. } \\
\text { Standardised documentation teminology } \\
\text { canreduce bias and confounding factors } \\
\text { in data mining which canin tum inform } \\
\text { clinical decision making in end of life } \\
\text { care. } \\
\text { Quality assurance: } \\
\text { Data mining techniques need to be } \\
\text { applied carefully to the underlying } \\
\text { datasets. Although generic at some } \\
\text { abstract level, these techniques involve } \\
\text { many technical steps that need to be } \\
\text { tailored to the underlying data, and their } \\
\text { complexity varies with the } \\
\text { characteristics of the data. }\end{array}$ \\
\hline $\begin{array}{l}\text { Steindal, S.A., } \\
\text { WergelandSørbye, L., } \\
\text { SchouBredal, I., }\end{array}$ & $\begin{array}{l}\text { To measure the level } \\
\text { of agreement } \\
\text { between data from }\end{array}$ & $\begin{array}{l}\text { Cross-sectional study } \\
\text { collecting data } \\
\text { retrospectively from }\end{array}$ & $\begin{array}{l}\text { Sample strategy } \\
\text { involved } \\
\text { interviewing nurses }\end{array}$ & $\begin{array}{l}\text { The resident } \\
\text { assessment instrument } \\
\text { for palliative care }\end{array}$ & $\begin{array}{l}\text { Interview data } \\
\text { compared with } \\
\text { electronic patient }\end{array}$ & $\begin{array}{l}\text { Main Findings: } \\
\text { The best agreements between nurse } \\
\text { interview data and EPR data were }\end{array}$ \\
\hline
\end{tabular}


Doody et al. Journal of Nursing 2018,

\section{Continuation of Table 4}

\begin{tabular}{|c|c|c|c|c|c|c|}
\hline $\begin{array}{l}\text { Lerdal, A. } \\
\text { (2011) } \\
\text { 'Agreement in } \\
\text { documentation of } \\
\text { symptoms, clinical } \\
\text { signs, and treatment } \\
\text { at the end of life: a } \\
\text { comparison of data } \\
\text { retrieved from nurse } \\
\text { interviews } \\
\text { and electronic patient } \\
\text { records using the } \\
\text { Resident Assessment } \\
\text { Instrument } \\
\text { for Palliative Care' } \\
\text { Norway }\end{array}$ & $\begin{array}{l}\text { interviews with } \\
\text { nurses and data from } \\
\text { EPR on the } \\
\text { prevalence of } \\
\text { physicalsymptoms, } \\
\text { clinical signs and } \\
\text { treatment during } \\
\text { hospitalised } \\
\text { patients' last three } \\
\text { days of life. }\end{array}$ & $\begin{array}{l}\text { August to December } \\
2007 \text { from electronic } \\
\text { patient records on } 9 \\
\text { wards (four medical } \\
\text { wards, one geriatric } \\
\text { ward, three surgical } \\
\text { wards and one } \\
\text { intensive care unit). } \\
\text { Records of patients } \\
\text { (n=112) were } \\
\text { reviewed for patients } \\
\text { that had died in the } \\
\text { hospital wards over } \\
\text { the five month } \\
\text { period. } 57 \text { female and } \\
55 \text { male patients. } \\
\text { Only nurses who } \\
\text { knewthe patient best } \\
\text { or who were at the } \\
\text { bedside when patients } \\
\text { died were } \\
\text { interviewed. }\end{array}$ & $\begin{array}{l}\text { delivering care to } \\
\text { the patient in the } \\
\text { last three days of } \\
\text { life, a total of } 112 \\
\text { patients within the } \\
\text { study. However } \\
\text { unclear as to how } \\
\text { many nurses were } \\
\text { interviewed } \\
\text { regarding the } 112 \\
\text { patients to make the } \\
\text { comparison } \\
\text { between nurses } \\
\text { report and } \\
\text { electronic patient } \\
\text { record. }\end{array}$ & $\begin{array}{l}\text { (RAI-PC), version } 9.0 \\
\text { was used to collect data } \\
\text { regarding patients' } \\
\text { physical symptoms, } \\
\text { signs and treatment } \\
\text { during the last three } \\
\text { days of life in the } \\
\text { hospital. The RAI-PC } \\
\text { is a } 72 \text { items instrument } \\
\text { collecting data on } \\
\text { (sociodemographic } \\
\text { status, health condition } \\
\text { (including symptoms } \\
\text { and clinical signs), oral } \\
\text { andnutritional status, } \\
\text { skin condition, } \\
\text { cognition, } \\
\text { communication, mood, } \\
\text { psychosocial well- } \\
\text { being, functional status, } \\
\text { continence, } \\
\text { medications, treatment } \\
\text { and procedures, } \\
\text { responsibility and } \\
\text { directives, social } \\
\text { support and discharge). } \\
\text { Structured interviews } \\
\text { conducted withnurses } \\
\text { using the RAI-PC and } \\
\text { if a nurse did not know } \\
\text { whether a symptom or } \\
\text { clinical sign was } \\
\text { present or whether } \\
\text { treatment was given, } \\
\text { the item was coded } \\
\text { 'missing data'. An } \\
\text { additional RAI-PC } \\
\text { assessment was filled } \\
\text { out for eachpatient } \\
\text { based on therr } \\
\text { electronic record. } \\
\text { ald }\end{array}$ & 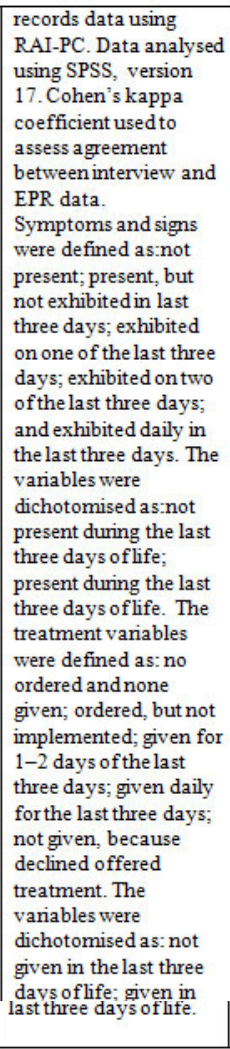 & $\begin{array}{l}\text { observed for dyspnoea, pain and nausea, } \\
\text { and poorest agreement on patient fatigue. } \\
\text { There was good agreement between } \\
\text { nurse interview data and EPR data for } \\
\text { the clinical sign falls. There was } \\
\text { moderate agreement forvomiting, } \\
\text { peripheral oedema and fever. There was } \\
\text { a fair level of agreement for } \\
\text { constipation, excessive sweating, } \\
\text { difficulty in falling or staying asleep, } \\
\text { difficulty in clearing airway secretion } \\
\text { and diarhoea. A poor level of agreement } \\
\text { was suggested for dry mouth, bloating } \\
\text { and sleep interfering with normal } \\
\text { functioning. The agreement was good } \\
\text { betweennurse assessments and EPR data } \\
\text { for suctioning and respirator bilevel } \\
\text { positive airway pressure (BiPAP) or } \\
\text { continuous positive airway pressure } \\
\text { (CPAP). There was moderate agreement } \\
\text { for the administering of intravenous } \\
\text { medication, oxygen therapy and wound } \\
\text { care. There was only fair agreement on } \\
\text { whether a tuming or repositioning } \\
\text { programme was applied. } \\
\text { Quality assurance: } \\
\text { Only focused on clinical signs and } \\
\text { symptoms so aspects of psychological, } \\
\text { spintual care etc. not included. } \\
\text { Does not capture nurse patient } \\
\text { interaction. } \\
\text { Only one hospital. } \\
\text { Retrospective data collected and recall } \\
\text { bias may have affected the completeness } \\
\text { of the documentation and the reliability. }\end{array}$ \\
\hline
\end{tabular}

theme to be compared and contrasted [22].

\section{Stage 5: Presentation of results}

The results of the review present the analysis which involved summarising results across studies into themes. Some studies are represented in more than one theme as they had several relevant findings. Two overarching themes emerged, symptom management and engagement. Overall studies were found to be of good methodological quality. All studies identified research aims, appropriateness of design, clear statements of findings and outlined the value of their research. All studies including an explicit statement of ethical approval and the qualitative study [23] provided contextual information of documentation of sixty records from two care units.

\section{Theme One: Symptom management}

Within the review of the studies identified it was evident that symptom management was the main focus of nurses' documentation. While a broad range of symptoms was identified across the studies reviewed (Table 5) only pain was identified as being specifically documented across all studies [23-27].

Pressure ulcer/wound care $[\mathbf{2 3}, \mathbf{2 4 , 2 6}]$ was identified in three studies, and fatigue $[\mathbf{2 4}, \mathbf{2 6}]$, intravenous medication $[\mathbf{2 3}, \mathbf{2 4}]$, nutrition $[23,26]$, oedema $[23,24]$, and oxygen therapy $[23,24]$ identified as documented within two studies. The remaining symptoms were identified as documented individually within a single study (Table 5). While pain was identified across all studies Almasalha et al [25] highlighted within their study that only $41.3 \%$ of care plans reviewed included pain documentation and $55 \%$ of patients were discharged to a hospice with worse pain than expected. While pain was rated on the Nursing Outcomes Classification System and recorded on the plan of care, when compared at discharge the most effective nursing intervention classification of pain intervention was only used in $13.6 \%$ of cases [25].

Documentation of assessment was evident in Esper and Walker's [27] audit, where assessment of bowel function at the time of narcotic prescription, assessment of narcotic efficacy on the return visit following initial or prescription change and assessment of bowel function post-narcotic prescription were highlighted. However, within Esper and Walker's [27] audit these assessments fell below the $80 \%$ compliance level set. Furthermore, documentation of the plan and appropriateness of the plan for addressing moderate to severe pain, and measures for addressing oral chemotherapy management also fell below the $80 \%$ level [27]. Furthermore, Ohlen et al [23] highlight that the documentation often began with a description of patient status followed by an assessment from the nurse, typically concerning medication, pain management, medical technical interventions and nutrition. 
Table 5. Symptom management identified across studies.

\begin{tabular}{|c|c|c|c|c|c|}
\hline Symptom & $\begin{array}{l}\text { Esper and Walker } \\
(2015)\end{array}$ & $\begin{array}{l}\text { Freeman et al. } \\
(2014)\end{array}$ & $\begin{array}{l}\text { Ohlen et al. } \\
(2013)\end{array}$ & $\begin{array}{l}\text { Almasalha et } \\
\text { al. (2012) }\end{array}$ & $\begin{array}{l}\text { Steindal et al. } \\
(2011)\end{array}$ \\
\hline Dyspnea & -- & $\sqrt{ }$ & -- & -- & -- \\
\hline Fever & -- & -- & $\sqrt{ }$ & -- & -- \\
\hline Constipation & -- & -- & -- & -- & $\sqrt{ }$ \\
\hline Delirium & -- & $\sqrt{ }$ & -- & -- & -- \\
\hline Excessive sweating & -- & -- & -- & -- & $\sqrt{ }$ \\
\hline Unexpected bleeding & -- & -- & $\sqrt{ }$ & -- & -- \\
\hline Vomiting & -- & -- & -- & -- & $\sqrt{ }$ \\
\hline Clinical sign falls & -- & -- & -- & -- & $\sqrt{ }$ \\
\hline CPAP & -- & -- & -- & -- & $\sqrt{ }$ \\
\hline BiPAP & -- & -- & -- & -- & $\sqrt{ }$ \\
\hline Diarrhoea & -- & -- & -- & -- & $\sqrt{ }$ \\
\hline Dry mouth & -- & -- & -- & -- & $\sqrt{ }$ \\
\hline Bloating & -- & -- & -- & -- & $\sqrt{ }$ \\
\hline Turning or repositioning & -- & -- & -- & -- & $\sqrt{ }$ \\
\hline Clearing airway secretion / suctioning & -- & -- & -- & -- & $\sqrt{ }$ \\
\hline Oral chemotherapy management & $\sqrt{ }$ & -- & -- & -- & -- \\
\hline Catherisation & -- & -- & $\sqrt{ }$ & -- & -- \\
\hline Appetite problems & -- & -- & $\sqrt{ }$ & -- & -- \\
\hline Sleep & -- & -- & -- & -- & $\sqrt{ }$ \\
\hline
\end{tabular}

\section{Theme Two: Engagement}

The theme of engagement was evident within two studies $[23,27]$ and encompassed the aspects of advice, coordination, consultation and personal support. Within Ohlen et al [23] study it was evident within the nursing documentation that nurses' advised patients and also gave the patient and/ or family support in different matters. These dialogues were concerned with providing information of different activities aimed at achieving a higher degree of well-being for the patient and family for example, aquatic training or creative work like painting [23]. Documentation highlighted that nurses comforted and supported patients to better cope with their present situation by being present and listening [23]. However, assessment of emotional well-being and the nursing plan for addressing emotional well-being fell below the $80 \%$ compliance level set [27].

Within nurses' documentation coordination and consultation consisted of nurses engaging with multidisciplinary team members regarding concerns about the patient or patient care [23]. This coordination and consultation was mainly performed from the office by telephone [23]. Within coordination and consultation care nurses provided personal assistance to the patient by assisting patients to book or check appointments, order mobility equipment, medical or personal aids and submit applications for travel services. These activities required a nursing assessment and the involvement of other professionals [23].

\section{Discussion}

Palliative care also strives to improve the sense of wellbeing of the person's informal support network, including family members and other caregivers [28]. However, from this review it is apparent that the gap between nurses recognising the significance of non-physical aspects of care and recognising the importance of documenting these persists. In the studies reviewed psychosocial, spiritual and cultural issues were rarely mentioned and documentation focused on physical symptoms and their management. This raises the question of what is considered by nurses as important to document and may reflect the apparent difficulty in writing about nonphysical aspects of care, compared to speaking about them and raises the question does this then become lost information? Findings from this review suggests that an inconsistency exists between nursing documentation and actual nursing activities performed and this is consistent with De Marinis et al [29] who identified this inconsistency at $47 \%(n=742$ nursing activities). Several researchers note that too often nurses perform the necessary direct nursing care and forget to document due to distractions, or that entries made in nursing documentation don't truly reflect the comprehensive care provided [7,29-31]. It may also be the case that nurses are concerned with direct nursing care and documentation can be sacrificed in times of heavy workloads and interruptions [32]. This has been further compounded in recent stringent economic times where under staffing has occurred [33] thus generating a further increase in direct nursing care workload and reduced focus on documentation [34]. However, as nurses have frequent and continual contact with patients throughout the day, their role in documenting any changes or deteriora- 
Doody et al. Journal of Nursing 2018,

tion in health status is critical [3].

Within this review it is evident that nurses don't clearly document what they do beyond physical care/symptom management and given the philosophy of palliative care there is a need to record physical, psychological, social and spiritual aspect of care. Nursing documentation can be seen as an opportunity for nurses to showcase what they actually do for the patient $[8,35]$. The purpose of nursing documentation is to provide a permanent record of nursing's contribution to patient outcomes [36]. This is attained if nursing documentation is a chronological verification of events showing how nursing interventions assimilate with the overall health care plan $[32,37]$. By presenting a record of the nurse's contribution to patient care, nursing documentation fulfils many functions, such as: supplying a framework for the continuity of patient care by communicating the patient's condition and care to all members of the health care team; providing evidence of care in a legal context; supporting the evaluation of the effectiveness of care; and acting as a database of nursing knowledge for information about future planning in health care, and can be used for risk planning, learning experiences for students, and the protection of patients' rights [32]. Given the long tradition of holistic care, nursing as a profession must create an environment of documentation that captures the essential and valued aspect of care.

This review reveals several inadequacies in the documentation of the nursing interventions afforded to patients in receipt of specialist palliative care. One of the main issues is the lack of documentation regarding the broad range of nursing interventions. Studies indicated the predominance of documentation of a biomedical nature and insufficient recording of psychological, social, cultural and spiritual aspects of care $[36,38]$. What may be helpful, is the use of standardised terminology to effectively demonstrate nursing knowledge within documentation and reduce bias and confounding factors in data mining which can in turn inform clinical decision making. Inadequate documentation of the steps of the nursing process is evident in nursing documents with insufficient documentation of assessment and the use of assessment tools $[36,39]$. The difficulty for nurses is the need to balance the delivery of care with the need to document the interventions. While documentation is reported as taking up to $50 \%$ of nurses' time per shift [40] this needs to be considered in light of the essential functions it serves. Poor communication is known to contribute significantly to the incidence of adverse events in healthcare [41] and is therefore an important objective of initiatives to improve patient safety. Adverse events can be reduced if a complete and accurate account of the patient's condition, care and response to care is available to all healthcare team members [42].

Documentation is essential for education, research and quality assurance $[43,44]$ and can be used to predict mortality [45]. According to Jefferies et al [46], quality nursing documentation must meet seven criteria: (1) patient-centred, (2) contains the actual work of nursing, (3) reflects the nurses' clinical judgment, (4) is presented in a logical sequence, (5) is written in real time, (6) records variances in care and (7) fulfils legal requirements. However, even with this knowledge documentation remains poor [42], with insufficient documentation of; assessment and nursing care and inaccuracy of documentation evident [47]. This is compounded by incongruence between what is documented and the actual physical status of the patient [48] and limited documentation of the work of nurses [35]. These inadequacies could be associated with challenges in two areas: the nurses' individual characteristics and work environments [49]. Nurses' perceptions and attitudes towards documentation impact the quality of how and what they document. While nurses consider documentation important they also consider it to be a burdensome task that takes them away from direct patient care [7]. Furthermore, knowledge of the nursing process, which forms the basis for nursing documentation, has been found to be insufficient [5]. In tandem with this is nurses awareness of increasing liability for their practise and as a result their documentation may be negatively affected $[\mathbf{5 0 , 5 1 ]}$.

The workplace environment can also contribute to poor documentation where heavy workloads, arduous documentation forms, fragmented language (i.e. use of colloquial language), inadequate resources and hospital culture all impact upon the quality of nurses' documentation and time to document $[35,42]$. Given the significance of nursing documentation and poor documentation practises, there have been calls and efforts to improve documentation quality [52]. Varying education strategies have been utilised to improve knowledge, skills and documentation practises these include: the introduction of a writing coach programme to improve documentation quality [32], augmenting training using written practise standards [53] and standardising nursing records, or a nursing model [54].

This review highlights a need for documentation to be developed in order to fully reflect how nurses integrate the philosophy of palliative care into their practice and for priority to be afforded to the documentation of nurses' work.In recent years the emphasis on quality has resulted in documentation being considered an important mechanism to evaluate care performance given by nurses [55]. It follows therefore that attention should be focused towards educating nurses in the area of documenting care so that nurses have the ability to describe on paper all elements of the holistic care they provide [29] and demonstrate how nursing interventions affects client outcomes [56]. Such educational programmes should provide nurses with the competence to document adequately but also encouraged nurses to view their documentation as a crucial aspect of care and recognise its value to other disciplines outside the profession [35]. However, while Jefferies et al [32] pre and post programme documentation audit, illustrated vast improvements in nursing documentation, Dehghan et al [57] found that nursing documentation did not improve after 
a two year clinical governance programme, which included education. In addition, it is recognised that regular auditing of clinical records can improve standards of record keeping and hence patient care [42]. However, from our review what is evident is that nurses need to move beyond policy aspiration to a regular daily practice within palliative care documentation. This commitment requires a willingness to change attitudes and practice, not merely by the introduction of policy or best practice imperatives, but by services, nurse managers and nurses adopting such a change in order for the potential of nursing documentation to be fully realised.

\section{Conclusion}

Nurses often state that "I did it; I just did not document it," but regulatory and legal views on documentation counter argue with the adage "if it was not documented; it was not done" [58]. Having a quality nursing document is important as it improves communication, avoids duplication, provides clear information, avoids irrelevant data been entered and inaccuracies occurring. Within palliative care nursing documentation needs to reflect the specialist and expert nursing afforded to patient and their families, moving beyond the recording of physical care and symptom management. Nurses need to demonstrate the value they place on all aspects of their care by documenting the total care provided. To support nurses' documentation of care, education and support is required, but this education has to occur within a culture of change within the whole organisation/service in order to achieve sustainable changes in attitudes and practice.

\section{Competing interests}

The authors declare that they have no competing interests.

Authors' contributions

\begin{tabular}{|l|c|c|c|c|}
\hline Authors' contributions & OD & MEB & SM & KS \\
\hline Research concept and design & $\checkmark$ & $\checkmark$ & $\checkmark$ & $\checkmark$ \\
\hline Collection and/or assembly of data & $\checkmark$ & $\checkmark$ & $\checkmark$ & $\checkmark$ \\
\hline Data analysis and interpretation & $\checkmark$ & $\checkmark$ & $\checkmark$ & -- \\
\hline Writing the article & $\checkmark$ & $\checkmark$ & -- & -- \\
\hline Critical revision of the article & $\checkmark$ & -- & $\checkmark$ & $\checkmark$ \\
\hline Final approval of article & $\checkmark$ & $\checkmark$ & -- & -- \\
\hline Statistical analysis & -- & -- & -- & -- \\
\hline
\end{tabular}

\section{Publication history}

Editor: Pamela gail Hawranik, Athabasca University, Canada. Received: 13-Oct-2017 Final Revised: 21-Dec-2017

Accepted: 05-Jan-2018 Published: 20-Jan-2018

\section{References}

1. World Health Organisation. National Cancer Control Programmes; policies and managerial guidelines. $2^{\text {nd }}$ edition. Geneva: World Health Organisation. 2002.

2. Gunhardsson I, Svensson A and Bertero C. Documentation in palliative care: nursing documentation in a palliative care unit--a pilot study. Am J Hosp Palliat Care. 2008; 25:45-51. | Article | PubMed

3. Voyer P, McCusker J, Cole MG, Monette J, Champoux N, Ciampi A, Belzile $\mathrm{E}, \mathrm{Vu} \mathrm{M}$ and Richard $\mathrm{S}$. Nursing documentation in long-term care settings: New empirical evidence demands changes be made. Clin Nurs Res. 2014; 23:442-61. | Article | PubMed

4. Potter PA Perry AG Astle B and Duggleby W. Canadian Fundamentals of Nursing. $5^{\text {th }}$ edition. Toronto: Mosby. 2014.

5. Ofi B and Sowunmi O. Nursing documentation: experience of the use of the nursing process model in selected hospitals in Ibadan, Oyo State, Nigeria. Int J Nurs Pract. 2012; 18:354-62. | Article | PubMed

6. Saranto K, Kinnunen UM, Kivekas E, Lappalainen AM, Liljamo P, Rajalahti $\mathrm{E}$ and Hypponen $\mathrm{H}$. Impacts of structuring nursing records: a systematic review. Scand J Caring Sci. 2014; 28:629-47. | Article | PubMed

7. Blair $W$ and Smith $B$. Nursing documentation: frameworks and barriers. Contemp Nurse. 2012; 41:160-8. | Article | PubMed

8. Hyde A, Treacy MP, Scott PA, Butler M, Drennan J, Irving K, Byrne $A$, MacNeela $P$ and Hanrahan M. Modes of rationality in nursing documentation: biology, biography and the 'voice of nursing'. Nurs Inq. 2005; 12:66-77. | Article | PubMed

9. Pearson $A$. The role of documentation in making nursing work visible. Int J Nurs Pract. 2003; 9:271. | Article | PubMed

10. Doody O, Slevin E and Taggart L. Intellectual disability nursing in Ireland: identifying its development and future. J Intellect Disabil. 2012; 16:7-16. | Article | PubMed

11. Doody O, Slevin E and Taggart L. The development of clinical nurse specialists (CNSs) in intellectual disability nursing in Ireland. J Intellect Disabil. 2012; 16:163-72. | Article | PubMed

12. Clancy TR, Delaney CW, Morrison B and Gunn JK. The benefits of standardized nursing languages in complex adaptive systems such as hospitals. J Nurs Adm. 2006; 36:426-34. | Article | PubMed

13. Karkkainen $O$ and Eriksson $K$. Recording the content of the caring process. J Nurs Manag. 2005; 13:202-8. | Article | PubMed

14. Nakate G Dahl D Drake KB and Petrucka P. Knowledge and Attitudes of Select Ugandan Nurses towards Documentation of Patient Care. A frican J Nurs Midwifery. 2015; 2:056-065.

15. Faull C de Caestecker S Nicholson A and Black F. Handbook of Palliative Care. $3^{\text {rd }}$ edition. Oxford:Wiley-Blackwell. 2012.

16. Whittemore $R$ and Knafl $K$. The integrative review: updated methodology. J Adv Nurs. 2005; 52:546-53. I Article | PubMed

17. Kahn KS, Kunz R, Kleijnen J and Antes G. Systematic reviews to support evidence-based medicine: How to review and apply findings of healthcare research. London: Royal Society of Medicine Press. 2003.

18. Pentland D, Forsyth K, Maciver D, Walsh M, Murray R, Irvine L and Sikora $S$. Key characteristics of knowledge transfer and exchange in healthcare: integrative literature review. J Adv Nurs. 2011; 67:1408-25. | Article | PubMed

19. Moher D, Liberati A, Tetzlaff J, and Altman DG. The PRISMA Group. Preferredreporting items for systematic reviews and meta-analyses: The PRISMA Statement. PLoS Med. 2009; 6:e1000097.

20. Critical Appraisal Skills Programme (CASP). Making sense of evidence. Critical Appraisal Skills Programme. Oxford: Critical Appraisal Skills Programme. 2013. | Website

21. Whittemore R. Combining evidence in nursing research: methods and implications. Nurs Res. 2005; 54:56-62. | Article | PubMed

22. Pfaff $K$, Baxter $P$, Jack $S$ and Ploeg J. An integrative review of the factors influencing new graduate nurse engagement in interprofessional collaboration. J Adv Nurs. 2014; 70:4-20. | Article | PubMed

23. Öhlén A Forsberg $C$ and Broberger $E$. Documentation of nursing care in advanced home care. Home Health Care ManagPract. 2013; 25:169-175.

24. Steindal SA, Sorbye LW, Bredal IS and Lerdal A. Agreement in documentation of symptoms, clinical signs, and treatment at the end of life: a comparison of data retrieved from nurse interviews and electronic patient records using the Resident Assessment Instrument for Palliative Care. J Clin Nurs. 2012; 21:1416-24. | Article I PubMed

25. Almasalha F, Xu D, Keenan GM, Khokhar A, Yao Y, Chen YC, Johnson A, Ansari $R$ and Wilkie DJ. Data mining nursing care plans of end-of-life patients: a study to improve healthcare decision making. Int J Nurs Knowl. 2013; 24:15-24. | Article | PubMed Abstract | PubMed FullText 
Doody et al. Journal of Nursing 2018,

26. Freeman S, Hirdes JP, Stolee P, Garcia J, Smith TF, Steel K and Morris JN. Care planning needs of palliative home care clients: Development of the interRAI palliative care assessment clinical assessment protocols (CAPs). BMC Palliat Care. 2014; 13:58. | Article I PubMed Abstract | PubMed FullText

27. Esper $P$ and Walker $S$. Improving documentation of quality measures in the electronic health record. J Am Assoc Nurse Pract. 2015; 27:308-12. I Article I PubMed

28. Canadian Hospice Palliative Care Association. A model to guide hospice palliative care. Canadian Hospice Palliative Care Association. Ottawa: Canadian Hospice Palliative Care Association. 2013. | Pdf

29. De Marinis MG, Piredda M, Pascarella MC, Vincenzi B, Spiga F, Tartaglini $D$, Alvaro $R$ and Matarese $M$. 'If it is not recorded, it has not been done!'? consistency between nursing records and observed nursing care in an Italian hospital. J Clin Nurs. 2010; 19:1544-52. I Article I PubMed

30. Furst CM, Finto D, Malouf-Todaro N, Moore C, Orr D, Santos J, Sutton $\mathrm{K}$ and Tipton $\mathrm{PH}$. Changing times: enhancing clinical practice through evolving technology. Medsurg Nurs. 2013; 22:131-4. | PubMed

31. Nielsen G, Peschel $L$ and Burgess A. Essential documentation elements: quality tool for the emergency department nurse. Adv Emerg Nurs J. 2014; 36:199-205. | Article | PubMed

32. Jefferies $D$, Johnson $M$ and Nicholls $D$. Comparing written and oral approaches to clinical reporting in nursing. Contemp Nurse. 2012; 42:129-38. | Article I PubMed

33. Geiger-Brown J, Rogers VE, Trinkoff AM, Kane RL, Bausell RB and Scharf SM. Sleep, sleepiness, fatigue, and performance of 12-hour-shift nurses. Chronobiol Int. 2012; 29:211-9. | Article | PubMed

34. Bailey ME, Moran S and Graham MM. Creating a spiritual tapestry: nurses' experiences of delivering spiritual care to patients in an Irish hospice. Int J Palliat Nurs. 2009; 15:42-8. | Article | PubMed

35. Jefferies D, Johnson $M$ and Nicholls D. Nursing documentation: how meaning is obscured by fragmentary language. Nurs Outlook. 2011; 59:e6-e12. | Article | PubMed

36. Wang N, Hailey D and Yu P. Quality of nursing documentation and approaches to its evaluation: a mixed-method systematic review. J Adv Nurs. 2011; 67:1858-75. | Article | PubMed

37. Kelley TF, Brandon DH and Docherty SL. Electronic nursing documentation as a strategy to improve quality of patient care. J Nurs Scholarsh. 2011; 43:154-62. | Article | PubMed

38. Hegarty M, Hammond L, Parish K, Glaetzer K, McHugh A and Grbich C. Nursing documentation: non-physical dimensions of end-of-life care in acute wards. Int J Palliat Nurs. 2005; 11:632-6. | Article | PubMed

39. Gjevjon ER and Helleso R. The quality of home care nurses' documentation in new electronic patient records. J Clin Nurs. 2010; 19:100-8. | Article | PubMed

40. Gugerty B Maranda MJ Beachley M Navarro VB Newbold S Hawk W Karp J Koszalka M Morrison S Poe SS and Wilhelm D. Challenges and Opportunities in Documentation of the Nursing Care of Patients. Baltimore:Documentation Work Group, Maryland Nursing Workforce Commission. 2007. I Pdf

41. The Joint Commission. Sentinel Event Data: Root causes by event type 2004-2012. Illinois: The Joint Commission. 2012. I Pdf

42. Prideaux $A$. Issues in nursing documentation and record-keeping practice. Br J Nurs. 2011; 20:1450-4. | Article | PubMed

43. DeLaune CS and Ladner KP. Fundamentals of nursing standards and practice. $4^{\text {th }}$ edition. New York: Cengage Learning. 2011.

44. Wilson S, Hauck Y, Bremner A and Finn J. Quality nursing care in Australian paediatric hospitals: a Delphi approach to identifying indicators. J Clin Nurs. 2012; 21:1594-605. | Article | PubMed

45. Collins SA, Cato K, Albers D, Scott K, Stetson PD, Bakken S and Vawdrey DK. Relationship between nursing documentation and patients' mortality. Am J Crit Care. 2013; 22:306-13. | Article | PubMed Abstract | PubMed FullText

46. Jefferies D, Johnson $M$ and Griffiths R. A meta-study of the essentials of quality nursing documentation. Int J Nurs Pract. 2010; 16:112-24. | Article I PubMed
47. Paans W, Sermeus W, Nieweg RM and van der Schans CP. Prevalence of accurate nursing documentation in patient records. J Adv Nurs. 2010; 66:2481-9. | Article | PubMed

48. Gunningberg $L$ and Ehrenberg $A$. Accuracy and quality in the nursing documentation of pressure ulcers: a comparison of record content and patient examination. J Wound Ostomy Continence Nurs. 2004; 31:32835. | Article | PubMed

49. Cheevakasemsook A, Chapman Y, Francis K and Davies C. The study of nursing documentation complexities. Int J Nurs Pract. 2006; 12:366-74. | Article | PubMed

50. Brown A. Nursing: Frequently in the bull's eye for noncompliance. Nurse Leader. 2013; 11:46-51.

51. Cartwright-Vanzant R. Medical record documentation: Legal aspects in neonatal nursing. Newborn Infant Nurs Rev. 2010; 10:134-137.

52. Whitcomb JJ, Seawright J, Flehan A and Echols L. A retrospective study evaluating responses time and survival from cardiopulmonary arrest: A creative inquiry project with undergraduate nursing students. DimensCrit Care Nurs. 2013; 32:50-53.

53. Considine J, Potter R and Jenkins J. Can written nursing practice standards improve documentation of initial assessment of ED patients. AustralasEmergNurs J. 2006; 9:11-18.

54. Tornvall E, Wahren LK and Wilhelmsson S. Advancing nursing documentation--an intervention study using patients with leg ulcer as an example. Int J Med Inform. 2009; 78:605-17. I Article I PubMed

55. Ginsburg L, Gilin D, Tregunno D, Norton PG, Flemons W and Fleming M. Advancing measurement of patient safety culture. Health Serv Res. 2009; 44:205-24. | Article | PubMed Abstract | PubMed FullText

56. Westra BL, Delaney CW, Konicek D and Keenan G. Nursing standards to support the electronic health record. Nurs Outlook. 2008; 56:258-266 e1. | Article | PubMed

57. Dehghan M, Dehghan D, Sheikhrabori A, Sadeghi M and Jalalian M. Quality improvement in clinical documentation: does clinical governance work? J Multidiscip Healthc. 2013; 6:441-50. | Article | PubMed Abstract | PubMed FullText

58. Bergen-Jackson K, Sanders S, Herr K, Fine PG, Titler M, Forcucci C, Reyes J and McNichol P. Determining Community Provider Practices in Hospices: The Challenges of Documentation. J Hosp Palliat Nurs. 2009; 11:334341. | Article | PubMed Abstract | PubMed FullText

\section{Citation:}

Doody O, Bailey ME, Moran S and Stewart K. Nursing documentation in palliative care: An integrative review. Journal of Nursing. 2018; 5:3.

http://www.hoajonline.com/nursing/2056-9157/5/3 